\title{
Vliv revize ČSN 757713 (2015) na výsledky stanovení abiosestonu
}

\section{PETR PUMANN}

Klíčová slova: abioseston - pitná voda - Česká republika - ČSN 757713 - vyhláška č. 252/2004 Sb.

\section{SOUHRN}

V článku je ukázáno, jak se revize metodické normy ČSN 757713 pro stanovení abiosestonu ve vodě z prosince 2015 a snížení limitní hodnoty z 10 \% na 5 \% v novele vyhlášky č. 252/2004 Sb. z dubna 2018 promítly do výsledků stanovení abiosestonu $\vee$ provozních laboratořích. $V$ rámci programů zkoušení způsobilosti pořádaných každoročně v letech 2011 až 2020 Státním zdravotním ústavem byly výsledky tř́ kol z pěti před revizí ČSN 757713 značně nadhodnoceny při srovnání se stanovením abiosestonu pomocí analýzy obrazu. U vzorků v dalších pěti kolech programu pořádaných po revizi normy k tak významnému nadhodnocení již nedocházelo. Výsledky rutinních kontrol pitné vody za období 2012 až 2019 (uložené v databázi IS PiVo) v době platnosti pưvodní metodické normy byly statisticky významně vyšší než výsledky po revizi. Byl také pozorován statisticky významný pokles v zastoupení výsledků překračujících 5 \% v období po novelizaci vyhlášky č. 252/2004 Sb. (0,07 \% výsledků) ve srovnání s obdobími před novelizací, tj. po revizi metodické normy (0,35 \%) i před ní (0,92\%).

\section{ÚVOD}

V pitné vodě se kromě mikroskopických organismů mohou vyskytovat i různé (většinou neživé) částice, které se řadí do ukazatele abioseston. Jedná se např. o produkty metabolismu železitých bakterií, zbytky schránek různých organismů (řas, prvoků, korýšů, hmyzu), pylová zrna, zbytky rostlinných pletiv, detritus, produkty koroze, krystaly uhličitanu vápenatého nebo pưdní částice. Ukazatel abioseston se podle vyhlášky č. 252/2004 Sb., která v současnosti určuje požadavky na kvalitu pitné vody, musí kromě textové informace o jeho složení obsahovat také kvantifikaci vyjádřenou jako pokryvnost zorného pole mikroskopu v komůrce Cyrus I po padesátinásobném zahuštění.

V legislativě ČR (resp. bývalého Československa) se abioseston jako „kvantitativní" ukazatel s limitem $10 \%$ pokryvnosti zorného pole poprvé objevil v roce 1991 v ČSN 757111 Pitná voda [1]. V době platnosti vyhlášky č. 376/2000 Sb. od ledna 2001 do dubna 2004 ze seznamu sledovaných ukazatelů sice vypadl, ale při další změně legislativy byl do něj již zmíněnou vyhláškou č. 252/2004 Sb. zase navrácen. Důvodem ke znovuzařazení nebyla jeho nepostradatelnost pro hodnocení kvality vody, ale především minimální pracnost stanovení, pokud se provádí společně se stanovením počtu mikroskopických organismů [2]. Je otázka, zda si někdo v pracovní skupině (včetně autora tohoto článku), v níz byla změna mikroskopických ukazatelů před novelizací diskutována, uvědomoval, že metoda podle ČSN 757713 z roku 1998 [3] je pro vzorky s větším množstvím abiosestonu obtižně reprodukovatelná. Každopádně již v roce 2007 byly popsány zásadní výhrady nejen k používané metodě (především k nevhodným odhadovým tabulím), ale také k nastavení limitní hodnoty ve vyhlášce (limitní hodnota $10 \%$ pro abioseston řádově neodpovídá limitní hodnotě 5 NTU pro zákal) [4]. V roce 2010 bylo rozhodnuto o prípravě revize metodické normy ČSN 757713 z roku 1998 [5]. Revidovaná norma byla vydána až koncem roku 2015 [6]. Obsahovala nové odhadové tabule, jejichž vhodnost byla ověřena ve třech sériích pokusů s účastníky determinačních kurzů [7, 8]. Poté, co byl revidovanou normou ČSN 757713 upraven metodický postup, mohlo být přistoupeno také ke snižení limitní hodnoty ve vyhlášce č. 252/2004 Sb. z 10 \% na 5 \% [9]. K této změně došlo v dubnu roku 2018 (vyhláškou č. 70/2018 Sb., která přinesla především změny týkající se rizikové analýzy), čímž byly úpravy navržené v roce 2007 [4] v zásadě dokončeny. Zda měl tento více než desetiletí trvající proces nějaký praktický dopad, tj. zda se změny odrazily ve výsledcích provozních laboratoří, je náplní tohoto článku.

\section{METODY}

Prvním zdrojem dat pro srovnání výsledků před a po revizi ČSN 757713 byl soubor výsledků z programu zkoušení způsobilosti (PZZ) Mikroskopický rozbor pitné a surové (povrchové) vody, který pořádá každoročně Státní zdravotní ústav (SZÚ). Do zpracování byla zahrnuta data za roky 2011 až 2020 (tedy pět let podle původní normy ČSN 757713 a pět let po její revizi). V uvedeném období dodalo výsledky pro ukazatel abioseston odhadem podle ČSN 757713 mezi 14 a 21 účastníky (tabulka 1). Do zpracování byly zahrnuty také výsledky získané pomocí analýzy obrazu (metoda nebyla předepsána, ale jednalo se vždy o postup rámcově popsaný v príspěvku z roku 2007 [4]). Analýzou obrazu vzorky zpracovávala jen menšina (ročně 3 až 6) účastníků (tabulka 1).

Druhým zdrojem dat byla databáze IS PiVo, kterou spravuji pracovníci Státního zdravotního ústavu. Do IS PiVo jsou zasílány výsledky rutinních kontrol pitné vody z veřejných vodovodů podle platné legislativy. Využita byla data za období leden 2012 až začátek prosince 2019. Toto období bylo rozděleno na tři nestejně dlouhé části:

— před revizí metodické normy ČSN 757713 (1. 1. 2012-30. 11. 2015),

- po revizi ČSN 757713 (1. 12. 2015-26.4. 2018),

- po revizi ČSN 757713 a zároveň po snížení limitu v novele vyhlášky č. 252/2004 Sb. z 10 \% na 5 \% (27. 4. 2018-2. 12. 2019).

V IS PiVo se nachází za uvedené období více než 126000 výsledků stanovení abiosestonu. Za stejné období jako u abiosestonu byla zpracována také data pro zákal.

K porovnání jednotlivých období u dat z IS PiVo byl použit Kruskalův-Wallisův test s následným tzv. mnohonásobným porovnáváním (po dvojicích), při němž se p-hodnoty korigují („zpř́isňuji“), aby se zohlednilo, že každá ze skupin vstupuje do porovnání několikrát. Dále byl v jednotlivých obdobích srovnáván počet překročení hodnoty $5 \%$ pokryvnosti abiosestonem pomocí Fisherova 
Tabulka 1. Počet účastníků (N), aritmetický průměr, medián a popis převládající složení abiosestonu v jednotlivých kolech PZZ Table 1. Number of participants (N), arithmetic mean, median and description of abioseston in particular rounds of PTS

\begin{tabular}{|c|c|c|c|c|c|c|c|}
\hline \multirow{2}{*}{ Rok } & \multicolumn{3}{|c|}{ Odhadem } & \multicolumn{3}{|c|}{ Analýzou obrazu } & \multirow{2}{*}{ Popis složení vzorku } \\
\hline & $\mathbf{N}$ & průmĕr & medián & $\mathbf{N}$ & průmĕr & medián & \\
\hline 2011 & 21 & 7,77 & 7,50 & 4 & 3,25 & 3,21 & sraženiny Fe malé a střední velikosti (desítky um) \\
\hline 2012 & 17 & 5,33 & 5,00 & 5 & 1,76 & 1,89 & sraženiny Fe malé a střední velikosti (desítky um) \\
\hline 2013 & 20 & 6,84 & 6,50 & 4 & 4,96 & 4,16 & převládaly světlé částice (krystaly) střední velikosti \\
\hline 2014 & 20 & 9,50 & 9,00 & 6 & 8,94 & 9,60 & Gallionella - jednotlivě i velké shluky (stovky um) \\
\hline 2015 & 21 & 9,28 & 9,00 & 5 & 3,18 & 3,20 & sraženiny Fe malé a střední velikosti (desítky um) \\
\hline 2016 & 17 & 4,97 & 5,00 & 4 & 3,46 & 3,38 & sraženiny Fe hlavně střední velikosti (desítky $\mu m$ ) \\
\hline 2017 & 14 & 6,15 & 6,25 & 4 & 6,01 & 5,76 & Gallionella - jednotlivě \\
\hline 2018 & 16 & 8,94 & 9,25 & 5 & 9,71 & 9,00 & sraženiny Fe především střední velikosti (desítky $\mu m$ ) \\
\hline 2019 & 14 & 4,77 & 4,75 & 5 & 3,39 & 3,57 & sraženiny Mn malé a střední velikosti (desítky um) \\
\hline 2020 & 16 & 11,0 & 10,75 & 3 & 7,62 & 7,21 & sraženiny Fe malé až velké velikosti (> 100 m) \\
\hline
\end{tabular}

exaktního testu s následným mnohonásobným porovnáním s Bonferroniho korekcí. Ke statistické analýze byl použit software Stata. Zpracování dat a další analýzy byly provedeny $\vee$ MS Excel.

\section{VÝSLEDKY A DISKUSE}

Vzorky pro stanovení abiosestonu v rámci PZZ pořádaných SZÚ se každoročně liší jak množstvím přítomného abiosestonu, tak jeho složením. Není tak téměř možné jen prosté srovnání výsledků před revizí metodické normy ČSN 757713 a po ní. K posouzení změn byly proto využity také výsledky abiosestonu stanoveného pomocí analýzy obrazu. Tato metoda je jednak výrazně méně subjektivní než stanovení odhadem podle ČSN 75 7713, ale především zúčastněné laboratoře (pravděpodobně) používaly po celé období stejnou metodu, takže Ize výsledek získaný analýzou obrazu považovat za referenční hodnotu, ke které je možné výsledky pomocí odhadu vztahovat. Také tato metoda má však různé nedostatky a i v ní hraje dojem analytika svou roli. Problematický je také mnohem menší počet laboratoří, které dodaly výsledek.

Srovnání výsledků obou metod $v$ deseti kolech PZZ je patrné z obr. 1 a tabulky 1. Téměř ve všech prípadech je střední hodnota (medián, aritmetický průměr) u stanovení analýzou obrazu nižší než u stanovení odhadem. Výjimku představovaly roky 2014 (medián) a 2018 (průměr). Výrazný rozdíl je především v letech 2012 a 2015. Důvod, proč v letech 2013 a 2014 rozdíl nebyl tak velký, Ize hledat především ve velikosti částic. $V$ pokusech s účastníky determinačních kurzů docházelo při využití odhadových tabulí z původní ČSN 757713 z roku 1998 k výraznému nadhodnocování výsledků především u vzorků s velkým množstvím malých částic [7]. U částic středních a velkých nebylo použití původní normy natolik problematické [7]. Ve vzorcích z let 2012 a 2015 byly právě malé částice hojně zastoupeny (tabulka 1). V roce 2014 byly prítomny stopky železité bakterie rodu Gallionella, které jsou také relativně malé a navíc protažené. V některých předchozích kolech PZZ (mimo zkoumané období) způsobovaly také výrazné nadhodnocení výsledků (např. v roce 2007 [10]). V roce 2014 se však kromě jednotlivých stopek bakterií rodu Gallionella vyskytovaly také jejich

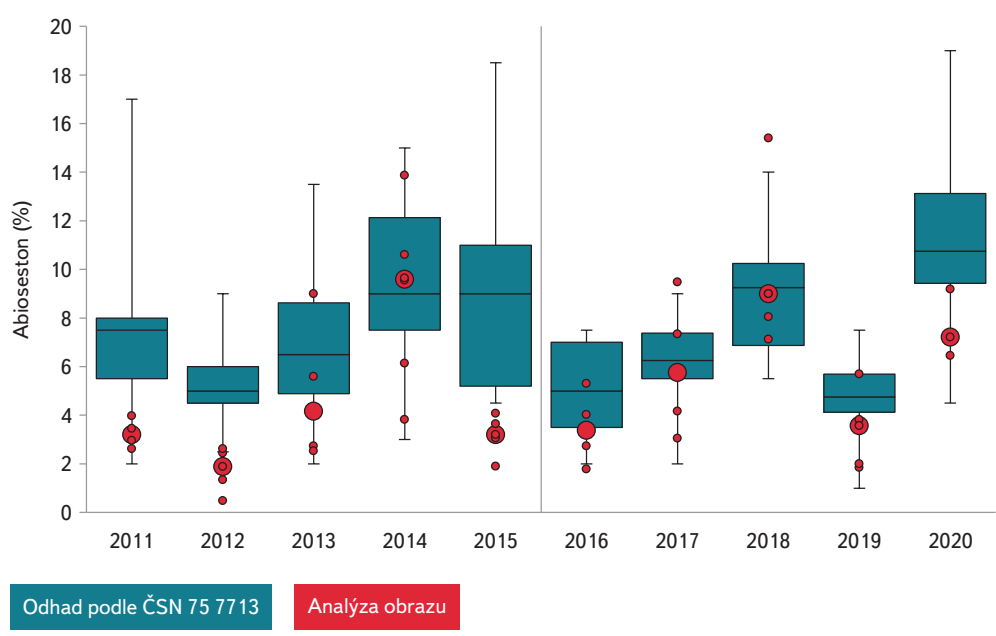

Obr. 1. Výsledky abiosestonu (odhadem podle ČSN 757713 a analýzou obrazu) v PZZ pořádaných SZÚ v období 2011-2020; střed krabicových grafů pro stanovení odhadem predstavuje medián, okraje krabiček 25. a 75. percentil; čárky na konci úseček (vousư) vyznačují nejvyšší a nejnižší hodnotu; výsledky analýzou obrazu jsou kvůli nízkému počtu účastníků zobrazeny jako medián (větší červený kruh) a výsledky jednotlivých účastníků (malé červené kruhy)

Fig. 1. Abioseston results (estimation according to the ČSN 757713 and image analysis) in the PTs organised by the National Institute of Public Health between 2011-2020; the central line of the box-plots shows the median of the results (by estimation according to the ČSN 75 771), the ends the 25th and 75th percentile and the whiskers the highest and lowest values; results by image analysis are shown (due to low numbers of participants) as the median (bigger red circle) and individual participant values (small red circles)

shluky velké až stovky $\mu m$. U takto velkých částic bylo pravděpodobné při využití odhadových tabulí z původní ČSN 757713 spíše podhodnocení výsledků [7], což efekt malých částic zřejmě vykompenzovalo. Celkový výsledek stanovení odhadem se tak od výsledku stanovení analýzou obrazu téměř nelišil. Ačkoliv 


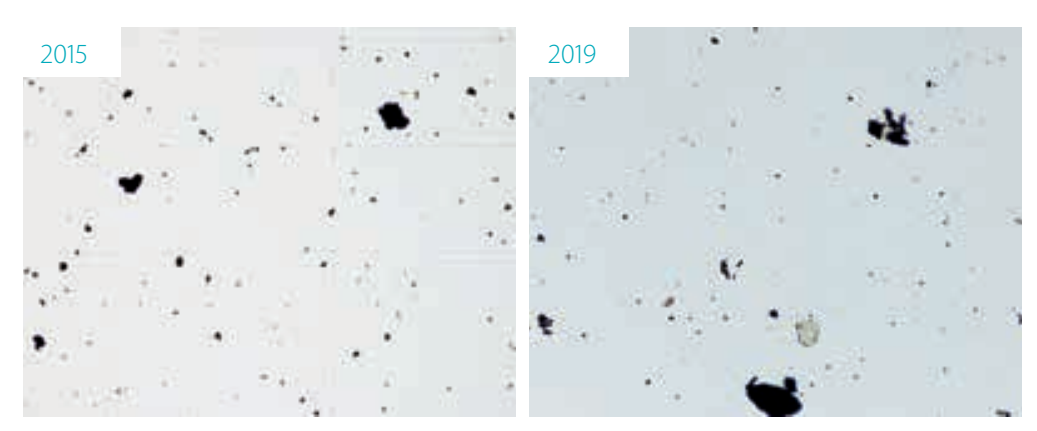

Obr. 2. Ukázky abiosestonu u podobných vzorků (z PZZ) před a po revizi metodické normy; pomocí analýzy obrazu bylo v obou kolech zjištěno zhruba stejné množství abiosestonu (mírně přes $3 \%$ ), pomocí odhadu podle ČSN 757713 byly získány výrazně odlišné výsledky (v roce 2015 před revizí více než 9 \%, v roce 2019 po revizi normy pouze necelých $5 \%$ )

Fig. 2. Examples of abioseston from two similar samples (from PTs) before and after the revision of the methodical standard; approximately equal amount of abioseston was found in both rounds by image analysis, different results were obtained by estimation according to the ČSN 757713 (in 2015 before the revision more than 9\%, in 2019 after standard revision slightly less than 5\%)

mají výsledky některých kol PZZ po revizi ČSN 757713 daleko do ideálního stavu (především kola v letech 2016, 2019, 2020), neobjevovaly se v nich tak velké rozdíly mezi stanovením abiosestonu odhadem a analýzou obrazu, jako tomu bylo před revizí metodické normy. To Ize dobře demonstrovat na vzorcích z let 2015 a 2019, které si byly velmi podobné jak složením abiosestonu, tak jeho množstvím (obr. 2). Zatímco výsledky získané analýzou obrazu v obou letech byly srovnatelné (tabulka 1), výsledky odhadem pokryvnosti podle původní ČSN 757713 z roku 1998 byly téměř dvojnásobné (více než $9 \%$ v roce 2015, necelých $5 \%$ v roce 2019 ).

Výsledky rutinních rozborů pitné vody z veřejných vodovodů uložených v databázi IS PiVo ukazují na vliv revidované normy ještě zřetelněji než výsledky PZZ. Období před revizí ČSN 757713 vykazuje při použití Kruskalova-Wallisova testu s následným mnohonásobným porovnáváním statisticky významně vyšší výsledky než obě období po revizi $(p<0,001)$. Rozdíly lze dobře pozorovat na obr. 3B i v tabulce 2. Největší přesun výsledků proběhl mezi kategoriemi $3 \%$ a $\leq 1 \%$, což znamená, že podle původních odhadových tabulí byly nadhodnocovány i výsledky na této relativně nízké úrovni. Proč byl přesun z kategorie 3 \% vyšší než z kategorie $2 \%$, je zrejejě dáno tím, že původní norma obsahovala pouze tabule pro 1, 3, 510,20 a $40 \%$. Místo výsledku $2 \%$, pro který nebyla odhadová tabule, laboratoře $v$ mnoha prípadech určily výsledek jako $3 \%$.
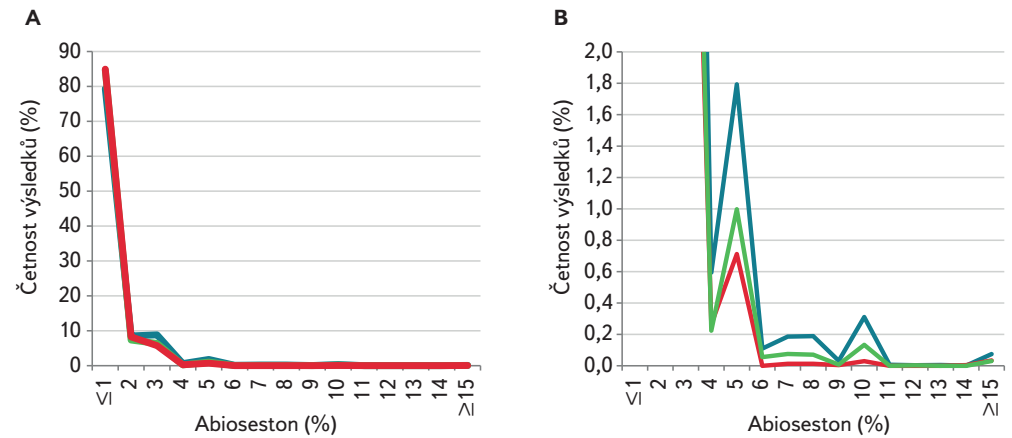

\section{Před revizi ČSN Po revizi ČSN Po změně limitu}

Obr. 3. A. Rozdělení výsledků (v procentech) stanovení abiosestonu ve veřejných vodovodech v období mezi lednem 2012 a začátkem prosince 2019 pro tři zkoumaná období; B. Stejný graf jako $3 A$ s jiným měřítkem na ose y obr. 3A, při kterém jsou lépe vidět změny v okolí 5 a $10 \%$ v jednotlivých obdobích

Fig. 3. A. Abioseston results distribution (in \%) from public water supply between January 2012 and beginning of December 2019 for three explored periods; B. The same chart as in $3 A$ with a different scale in the $y$-axis, where changes near 5 and $10 \%$ of abiosestone are clearly apparent

Tomu odpovídá i mírně vyšší zastoupení výsledků 3 \% ve srovnání s 2 \% (obr. 3A, tabulka 2), i když ve skutečnosti nelze takové rozdělení dat u tohoto ukazatele předpokládat. Zvýšení četnosti výsledků je možné pozorovat i pro 5 a 10 \%. V př́ipadě 5 a $10 \%$ se však projevuje i dalši efekt, kterým je obecná tendence preferovat "(půl)kulatá“ čísla. Proto žrejmě výsledek 4 \% je mnohem méně častý než 5 \% (i když z rozdělení dat je evidentní, že by to tak být ve skutečnosti nemělo) nejen v období před revizí normy, ale i po ní, a to přesto, že nové tabule jsou připraveny v intervalu od 1 do $12 \%$ pro každé celé procento.

Vliv snižení limitu v dubnu 2018 na výsledky abiosestonu v rutinních rozborech pitné vody, jenž byl testován jako rozdíl období po revizi ČSN 757713 do novelizace vyhlášky č. 252/2004 Sb. v dubnu 2018 a období od novelizace po začátek prosince 2019, při použití Kruskalova-Wallisova testu s následným mnohonásobným porovnáváním, nebyl prokázán. Při srovnání zastoupení výsledků vyšších než 5 \% pomocí Fisherova exaktního testu s následným mnohonásobným porovnáním s Bonferroniho korekcí však statisticky významný rozdíl mezi všemi porovnávanými obdobími zjištěn byl $(p<0,001)$. Tento rozdíl je dobře patrný na obr. 3 a v tabulce 2. V intervalu 6 až $10 \%$ bylo před novelizací necelých 0,4\%, po novelizaci jen necelých $0,1 \%$ všech hodnot. V absolutních číslech se jedná o několik desítek výsledků ročně, které před novelizací splňovaly limit a po ní by už byly nad ním.

Tabulka 2. Prưměrný roční počet vzorků a relativní četnost (v \%) pro výsledky abiosestonu z veřejných vodovodů v databázi IS PiVo od ledna 2012 do začátku prosince 2019 Table 2. Annual average of number of samples and relative frequency (\%) for abioseston results in public supply in the IS PiVo database between January 2012 and the beginning of December 2019

\begin{tabular}{|c|c|c|c|c|c|c|c|c|c|c|c|c|c|}
\hline \multirow{2}{*}{ Vzorky } & \multirow{2}{*}{ Období } & \multicolumn{11}{|c|}{ Abioseston (\%) } & \multirow{2}{*}{$\Sigma$} \\
\hline & & $\leq 1$ & 2 & 3 & 4 & 5 & 6 & 7 & 8 & 9 & 10 & $>10$ & \\
\hline \multirow{3}{*}{$\mathrm{N} / \mathrm{rok}$} & před revizí ČSN & 12752 & 1370 & 1417 & 96 & 288 & 18 & 30 & 30 & 5 & 50 & 15 & 16070 \\
\hline & po revizi ČSN & 14008 & 1212 & 1050 & 37 & 165 & 9 & 12 & 12 & 1 & 22 & 2 & 16529 \\
\hline & po změně limitu & 12461 & 1211 & 841 & 39 & 104 & 0 & 2 & 2 & 1 & 4 & 2 & 14667 \\
\hline \multirow{3}{*}{$\%$} & před revizí ČSN & 79,4 & 8,52 & 8,82 & 0,59 & 1,79 & 0,11 & 0,19 & 0,19 & 0,03 & 0,31 & 0,09 & 100 \\
\hline & po revizi ČSN & 84,7 & 7,33 & 6,35 & 0,22 & 1,00 & 0,06 & 0,08 & 0,07 & 0,01 & 0,13 & 0,01 & 100 \\
\hline & po změně limitu & 85,0 & 8,25 & 5,74 & 0,26 & 0,71 & 0,00 & 0,01 & 0,01 & 0,00 & 0,03 & 0,01 & 100 \\
\hline
\end{tabular}


Jejich absenci v období po novelizaci lze vykládat různě - zlepšením stavu vody (nápravná opatření provedená při nevyhovujícím výsledku), selekcí reportovaných výsledků (z většího množství výsledků jsou do IS PiVo poslány jen ty lepší) či již na úrovni analytika, který (at’ už vědomě či podvědomě) se rozhodne pro limit nepřekračující výsledek.

Při intepretaci výsledků je třeba mít na paměti rovněž to, že obě změny v dokumentech (tedy revize ČSN 757713 v roce 2015 a novelizace vyhlášky č. 252/2004 Sb. z roku 2018) mají sice jasně určené datum účinnosti, ale že ve skutečnosti se nejednalo o ostrý preděl ze dne na den. O tom, že jsou staré odhadové tabule špatné a že se připravují nové, rada laboratoří věděla předem (přinejmenším tam, kde se jejich pracovníci účastnili pokusů s novými tabulemi $v$ rámci kurzů $[7,8])$, takže jejich výsledky už mohly být ovlivněny před datem účinnosti. Navíc i k původním tabulím mohly laboratoře pristupovat s vědomím, že výsledky získané s jejich pomocí jsou obvykle nadhodnocené. Na nic takového však data z IS PiVo neukazují. Při srovnání dat z roku 2015 s předcházejícími lety není patrný žádný rozdíl. V úvahu připadá i opačný efekt, tedy že inned s nástupem účinnosti revidované normy (tedy po 1. 12. 2015) nezačaly všechny laboratoře pracovat s novými tabulemi. Při srovnání výsledků z let 2016 a 2017 však nebyl patrný žádný rozdíl.

Samozřejmě není ani možné předem vyloučit možnost, že zjištěné změny ve výsledcích abiosestonu byly způsobeny nějakým jiným faktorem než změnou metodické normy (např. klesajícím počtem nerozpuštěných částic ve veřejných vodovodech). Provedli jsme proto i srovnání s daty pro zákal (ukazuje také na množství ve vodě prítomných částic) za stejné období. Žádné rozdíly jako u výsledků abiosestonu však patrné nebyly.

\section{ZÁVĚR}

Výsledky PZZ, které každoročně pořádá SZÚ, i výsledky z rutinních rozborů z veřejných vodovodů ukazují na to, že se použití revidované metodické normy ČSN 757713 z konce roku 2015 v praxi zretelně projevilo. Ubyla značná část vysokých hodnot, což byly pravděpodobně většinou výrazně nadhodnocené výsledky, za které mohly především špatné odhadové tabule v původní normě. Celkově se přesunulo zhruba $5 \%$ výsledků z vyšších hodnot do kategorie $\leq 1 \%$. Snížení limitní hodnoty z 10 \% na 5 \% lze ve výsledcích rutinních rozborů z veřejných vodovodů také pozorovat. Do budoucna by bylo vhodné uvažovat o dalším snížení limitu ve vyhlášce č. 252/2004 Sb., protože i stávajících $5 \%$ je poměrně vysoká hodnota (vzhledem $\mathrm{k}$ limitu pro zákal). $V$ této souvislosti je vhodné připomenout, že původní návrh před zařazením abiosestonu do legislativy (ČSN 75 7111) [1] byl 3 \%. Zvýšen na 10 \% byl až v rámci připomínkových ř́zení především z metodických důvodů [11].

\section{Poděkování}

Vznik príspěvku byl podpořen v rámci MZ ČR - RVO (Státní zdravotní ústav - SZÚ, IČ 75010330). Danielovi Weyessovi Garimu děkuji za prípravu dat z IS PiVo. Marku Malému děkuji za provedeni statistické analýzy a upresnění některých formulací.

\section{Literatura}

[1] ČSN 757111 Pitná voda. Účinnost od 1. 1. 1991, 24 str.

[2] PUMANN, P. Biologické ukazatele v novelách vyhlášek Ministerstva zdravotnictví pro pitnou vodu a koupaliště. Sborníkze semináre Aktuální otázky vodárenské biologie: 16-23, 2003.

[3] ČSN 757713 Jakost vod - Biologický rozbor - Stanovení abiosestonu. červenec 1998. 16 str.

[4] PUMANN, P. a POUZAROVÁ, T. Kvantitativní stanovení abiosestonu. Sborník konference Vodárenská biologie 2007, s. 19-24.
[5] FREMROVÁ, L. Prověrení norem ČSN a TNV z oboru jakosti vody - biologické metody. HYDROPROJEKT CZ, a. S., 2010.

[6] ČSN 757713 Kvalita vod - Biologický rozbor - Stanovení abiosestonu. listopad 2015. 32 str.

[7] PUMANN, P. Některé aspekty stanovení abiosestonu odhadem pokryvnosti zorného pole. Sborník konference Vodárenská biologie 2014, s. 15-20.

[8] PUMANN, P., ŘíHOVÁ AMBROŽOVÁ, J. a FREMROVÁ, L. Revidovaná norma ČSN 757713 Kvalita vod - Biologický rozbor - Stanovení abiosestonu. Sborník konference Vodárenská biologie 2016, s. 11-17.

[9] PUMANN, P. Další vývoj mikroskopických ukazatelů v pitné vodě s ohledem na zavádění posouzení rizik. Sborník z konference Vodárenská biologie 2017, 1.-2. 2. 2017, Praha, 2017, s. 15-19.

[10] Závěrečná zpráva z PT\#V/6/2007 Stanovení mikroskopického obrazu v pitné vodě, Praha, červen 2007. Dostupné na http://www.szu.cz/uploads/documents/chzp/voda/pdf/pt/pt6_2007z.pdf

[11] POPOVSKÝ, J. Diskusní př́spěvek. Aktuální otázky vodárenské biologie, 1986, s. 155-158.

\section{Autor}

Mgr. Petr Pumann

$凶$ petr.pumann@szu.cz

ORCID: 0000-0002-8199-1883

Státní zdravotní ústav

Príspěvek prošel lektorským řízením.

DOI: $10.46555 /$ VTEI.2020.12.006

\section{INFLUENCE OF THE REVISION OF ČSN 757713 (2015) ON THE RESULTS OF ABIOSESTONE DETERMINATION}

\section{PUMANN, $P$.}

National Institute of Public Health

Keywords: abioseston - drinking water - Czech Republic ČSN 757713 - Decree No. 252/2004 Coll.

It is shown in the article, how the revision of the Czech methodical standard for abioseston analysis in water ČSN 757713 from December 2015 and the lowering of the limit value for abioseston in the Decree No. 252/2004 Coll. (drinking water quality) from 10 to $5 \%$ influenced results of routine laboratories. The results of three rounds (from five) of the proficiency testing programmes organised annually between 2011 and 2020 by the National Institute of Public Health before the revision of ČSN 757713 were overestimated substantially in comparison with the abioseston results obtained by image analysis. There were not such overestimations within the rounds after the standard revision. The results of routine drinking water monitoring (stored in the IS PiVo database) from the period 2012-2019, when the original methodical standard was valid, were significantly higher than the results after revision. The statistically significant decrease of results higher than $5 \%$ in the period after the Decree No. 252/2004 Coll. amendment (0.07\% of results higher than $5 \%$ ) comparing the periods before the amendment, i.e., after the revision of the methodical standard (0.35\%) and before this revision (0.92\%). 